\title{
Meet Our Editorial Board Member
}

\author{
P. Illes \\ Rudolf Boehm Institute of Pharmacology and Toxicology, Haertelstrasse 16-18 \\ University of Leipzig, 04107 Leipzig \\ Germany
}

Peter Illes has studied medicine and has been an Associate Professor at the

Department of Pharmacology of the University of Freiburg. He is also a Full

Professor and the Director at the Department of Pharmacology of the University of

Leipzig, Germany. He has obtained numerous awards and distinctions; he is also a

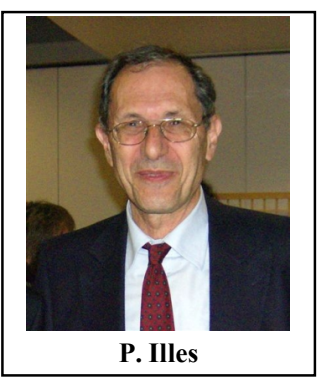

member of several professional organizations such as the Academia Europaea or the Czech Learned

Society. He has been awarded as an honorary Doctorate in Budapest, Hungary, and honorary

Professorates in Shanghai and Chengdu, China. He is a neuroscientist with special emphasis on two types

of ATP-sensitive receptors, belonging to the $\mathrm{P} 2 \mathrm{X} 3$ and $\mathrm{P} 2 \mathrm{X} 7$ class.

\section{SELECTED PUBLICATIONS}

[1] Rozmer, K., Gao, P., Araújo, M.G.L., Khan, M.T., Liu, J., Rong, R., Tang, Y., Franke, H., Krügel, U., Fernandes, M.J.S., Illes, P.: Pilocarpine-induced status epilepticus increases the sensitivity of P2X7 and P2Y1 receptors to nucleotides at neural progenitor cells of the juvenile rodent hippocampus. Cerebral Cortex 27: 3568-3585, 2017.

[2] Illes, P., Khan, T.M. and Rubini, P.: Neuronal P2X7 receptors revisited: Do they really exist? J. Neurosci. 37: $7049-7062,2017$.

[3] Kowalski, M., Hausmann, R., Schmid, J., Dopychai, A., Stephan, G., Tang, Y., Schmalzing, G., Illes, P. and Rubini, P.: Flexible subunit stoichiometry of functional human P2X2/3 heteromeric receptors. Neuropharmacology 99: 115-130, 2015.

[4] Sperlagh, B., and Illes, P.: The P2X7 receptor: an emerging target in CNS diseases. Trends Pharmacol. Sci. 35: 537-547, 2014.

[5] Kowalski, M., Hausmann, R., Grohmann, M., Dopychai, A., Franke, H., Nieber, K., Schmalzing, G., Illes, P., and Riedel, T.: Conformational flexibility of the agonist binding jaw of the $\mathrm{hP} 2 \mathrm{X} 3$ receptor is a prerequisite for channel opening. Br. J. Pharmacol. 171: 5093-5112, 2014.

[6] Ficker, C., Rozmer, K., Kato, E., Ando, R.D., Schumann, L., Krügel, U., Franke, H., Sperlagh, B., Riedel, T., and Illes, P.: Astrocyteneuron interaction in the substantia gelatinosa of the spinal cord dorsal horn via P2X7 receptor-mediated release of glutamate and reactive oxygen species. Glia 62: 1671-1686, 2014. 